\title{
Miloslav Petrusek o historické sociologii, dějinách a literatuře
}

\author{
PTAL SE JAROSŁAW KILIAS
}

\section{Miloslav Petrusek about Historical Sociology, History and Literature}

Zdá se mi poněkud paradoxní, že i když jsi beze sporu kmenovým autorem našeho časopisu, v e-mailové korespondenci jsi naznačoval, že vlastně nejsi historickým sociologem. Nejde pritom jen o Tebe. Musím ř́ci, že já osobně jsem byl zpočátku poněkud skeptický vưči nápadu vydávat takovýto časopis, protože mám dojem, že v české (ale i v polské) sociologii zájem o historickou sociologii a problematiku dèjin vi̊bec byl dlouhou dobu spíše okrajový. Zdá se, že zájem o dějinně-sociologickou problematiku byl a možná dosud je silnější spíše u historiků (v české produkci stačí připomenout výborný časopis Dějiny-teorie-kritika). Bylo tomu opravdu tak? Na druhé straně se zdá, že se to ted’ možná trochu

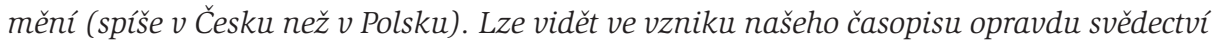
určité re-orientace?

Začnu tedy kategorickou tezí - solidní sociologie, která se neomezuje na deskripci každodennosti, se bez „historické dimenze“ dělat nedá. Neznamená to ani návrat k archaickému evolucionismu ani k poněkud zjednodušenému metodologickému požadavku, že „vysvětlit sociální jev znamená porozumět jeho vzniku a vývoji“. „Historická dimenze“ je to, čemu kdysi spisovatel Vančura říkal „vědomí souvislosti“, řekněme tedy „diachronické souvislosti“: ani ty dnešní tolik nás trápící „deviantní“ a „patologické“ jevy, jako je korupce, úplatkářství všeho druhu, podvody nehorázných rozměrů, beztrestnost viditelných viníků nejsou bez historických kořenů, nevznikly ze vzduchoprázdna. Jonathan Turner - a to je dost podstatné pro porozumění povaze naší vědy dnes a tady - napsal v knížce o klasicích sociologie, že „celý vývoj po Comtovi je velkou zradou na otci zakladateli“ a podstata té zrady spočívá prý v tom, že se sociologie „historizovala“. Marx historizoval, Weber historizoval, o Spencerovi nemluvě, v čemž Turner vidí „Zradu“ - sociologie totiž přestala usilovat o to, aby byla nomotetickou vědou, jak si Comte přece přál. Dnes víme, že je to představa sice krásná, ale iluzorní: sociologie nikdy nomotetickou vědou nebude. To ale současně znamená - to přece vidíme na každém kroku, že se nám před očima roztříštila na ty, kteří zkoumají témata vskutku závažná (všimněte si ale, kolik „historična“ je v Bělohradském, Kellerovi, Přibáňovi, jak historicky je fundován Barša, Skovajsa...), na ty, jež zkoumají „aktuální prkotiny“ (to jsou ty záchodky jako součást veřejného prostoru - ačkoliv existuje solidní studie o záchodcích psaná na bázi historické sociologie, tu ale autor/ka samozřejmě nezná), na ty, kteří píší pod vlivem mód, přičemž většinou jde o více či méně inteligentní recepci toho, co již někdo někde napsal (například nečetl jsem jedinou studii z gender studies - a že jde o módu par excellence snad netřeba dokládat - která by se podívala třebas na Masaryka jako na „českého feministu“ a vášnivého čtenáře „ženské literatury“ nebo o tom, že „válka nemá ženskou tvářc“, jak se jmenuje jedna z knih tomu tématu věnovaných - ženy ve válce se odbudou na šesti odstavcích pětisetstránkové knihy psané muži) a konečně na ty, kteří usilovně tvoří něco originálního 
a původního - s rizikem, že se stanou nesrozumitelní nebo - a to je obvyklejší - bez jakékoliv solidní znalosti dějinných souvislostí. Jak chcete psát o transformaci či „přerodech“ bez znalosti nejen teorií revoluce a reforem, ale i faktické báze, na nichž jsou založeny. Chybí komparace historická i prostorová. Píše se o transformacích a dynamice (?) vývoje v Česku a nikdo nečte Poláky, o Rusech nemluvě. A co se tam toho napsalo a v jakých dějinných souvislostech! Shrnuto, nezájem o dějinný kontext je dědictví doby a produkt nevědomosti a neochoty zvládat novou materii. Bud’me se svým žurnálem - aspoň pokud budeme existovat - světýlkem naznačujícím cestu.

Přiznám se, že nesdílím tento kritický pohled, ani na českou společnost, ani na českou vědu. Nejsem si také jist tím, zda je možné dávat pod společný jmenovatel všechen zájem o širší časovou perspektivu? Tímto způsobem by bylo možné třeba dokázat, že i Comte byl „historický sociolog“! Tak co vlastně podle Tebe je historická sociologie?

Posouzení, zda je můj pohled na českou sociologii a společnost př́liš kritický, je věcí vkusu a možná trochu zkušenosti. Ty většinou ze stavu Polska v tomto ohledu obvykle taky nevyskakuješ nadšením, zatímco já tiše závidím. Podstatnější je teze, že požadavek historického kontextu při zkoumání konkrétních sociálních jevů téměř nutně dělá z Comta historického sociologa, čímž by se pojem „historická sociologie“ prostě zcela rozmazal. Myslím, že při pozorném čtení se dá snadno zjistit, že Comte, ale ani evolucionista Spencer neměli pro historické kontexty valný smysl. Jejich téměř současník Marx naopak - i v Kapitálu jsou části propojující teorii s historickým pohledem (tř̌ebas kapitola o prvotní akumulaci), jeho zdánlivě jen dobové studie, zejména Tř́ídní boje ve Francii historické zakotvení mají. Ostatně kapitolka o roli buržoazie ve vývoji kapitalismu v Komunistickém manifestu je ukázkovým př́kladem „historického kontextu“. Spor o tom, kam koho řadit, je bud’ předmětem vážného bádání (ne vždy nutně poučeného), nebo prosté etiketizace.

Na otázku, co je historická sociologie se samožrejmě dá odpovědět verbální „definicí“, jež ale bude vždycky sporná - jedni zdůrazňují „ontologickou dimenzi“ (jde o studium společností v čase, což je nejen banální, ale i nepřesné), jiní „metodologickou“ (jde o studium sociálních jevů na základě historických pramenů primárních i sekundárních, což je stěží realizovatelné, protože prakticky žádný sociolog neumí s historickými prameny pracovat a obvykle netuší ani co je „kritika pramenů“ atd.).

Dále odpovím drobným úskokem. V Čechách jsme měli ke konstituci čehosi, co by historické sociologii bylo blízko, „nakročeno“ dvakrát, a to pomíjím, že první česká studie přímo nazvaná Úvod do historické sociologie vyšla z pera Františka Modráčka v roce 1927 a vůbec to nebyla nezávazná spekulace v tradici některých dokonce klasických filosofií dějin. Poprvé v 60. letech, kdy z iniciativy Josefa Polišenského, historika první kategorie, vycházela edice Otázky dějin - v roce 1967 v ní vyšla proslulá práce Carrova Co je historie?, kde se čte ona slavná věta - „čím více bude historie sociologickou a čím více bude sociologie historickou, tím lépe pro obě“ (str. 68), ale kde lze také najít kritickou analýzu Toynbeeho, ale i Popperova konceptu „historicismu“, na nějž si dnes netroufáme sáhnout. V tomtéž roce vychází stejně proslulá Blochova Obrana historie - v době, kdy jsem začínal učit sociologii (1967), právě z této knížky jsem se naučil hledat korektivy k pozitivistické metodologii empirického výzkumu. A konečně ještě v roce 1970 vychází Historie jako uměni a jako věda $\mathrm{H}$. Stuarta Hughese - je to jakási prehistorie tématu dnes tolik diskutovaného, totiž o povaze narativity v historických a sociálních vědách, téma 
rozvinuté tedy dávno před Whiteovou Metahistorií. Teprve potom jsem četl Huhghesovu Consciousness and Society s podtitulem „Re-orientace evropského sociálního myšlení v letech 1890-1930“ z roku 1957. Žádné nudné „dějiny sociálních teorií“, přímo drama evropského intelektuálního selhání, ostatně - dodnes jedna z mých knih oblíbených. Jistě, namítneš, ale to jsou „dějiny ideji““ - zajisté, nicméně pokud jsou ideje integrovány do sociálního kontextu, pak jde především o dobré porozumění roli idejí v dějinách, o čemž zajímavě píše zesnulá Jaroslava Pešková. V tomto ohledu osobitým zpơsobem navazuje na Hughese Burrowova Krize rozumu (Evropské myšleni 1848-1914) - i to je „historická sociologie“ idejí. To druhé nakročení bylo jaksi nevědomé. Přeložili jsme kdysi - v dobách „normalizačního temna“ knihu Jacoba L. Talmona O pưvodu totalitní demokracie, která je pro mě zajímavá i tím, že když jsem k ní psal na konci 80. let doslov (internet nebyl!), nedokázal jsem onoho Talmona vůbec identifikovat. Jím slíbené pokračování o vývoji totalitní demokracie po Francouzské revoluci již ale nevyšlo, náš samizdatový překlad vyšel až v roce 1998. Je ostatně příznačné, že Talmon děkuje Carrovi, Tawneyovi, ale i Isaiahovi Berlinovi. Žádný z těch podnětů nebyl u nás domyšlen a rozvinut, ačkoliv se to nabízelo téměř samo sebou. Dnes u nás vycházejí desítky historických knih, které jsou na onom „carrovském pomezí“, ale myslím, že mezi sociology mají podstatně menší ohlas, než si zaslouží.

V poslední době vychází jak v Česku, tak v Polsku celá rada prací (v Polsku ovšem spíše $z$ pera mladých historiků než sociologů) týkajících se období „reálného socialismu“. Není to právě začátek jakési nové české historické sociologie?

Nejsem si tím jist. Především žádnou přemíru zájmu o normalizační období, ba ani o klasický totalitarismus nevidím, nadto nezřídka jde o velmi plytké a nepoučené texty (zde právě reálně chybí ona fundovaná „historickosociologická“ dimenze), nadto mi dost vadí, že konceptuální rámce, pokud jaké jsou, jsou mechanicky přejímány z anglosaské literatury, kde je samožrejmě k dispozici několik kvalitních knížek (zejména Orlando Figes je modelovým př́kladem „sociálního historika“, který se dokáže pohybovat stejně kvalifikovaně na makro i mikrosociální úrovni analýzy a narace ve výkladu ruských dějin a kultury). Exemplární nepoučenost je vidět například na fenoménu socialistického realismu, z něhož se stal doslova rafinovaný byznys. Dnes je s odstupem téměř šedesáti let (éra socialistického realismu jako absolutně závazné doktríny skončila u nás kolem roku 1958) vnímán pouze jako kuriozita, a tak je taky prezentován. Nadto - a to je chyba, které by se historik (ale ani historik umění) dopustit neměl, se mísí produkty („artefakty“), jež byly vytvořeny skutečně podle „kánonu“, s tím, co pouze časově synchronizovalo (Švabinský opravdu nebyl socialistický realista, i když se jeho portrét Julia Fučíka stal jakýmsi „znamením doby“). Česká historická sociologie by se měla revitalizovat kooperací s historiky, jinak to prostě nejde, tedy prací na společných tématech. O tom, že časový úsek, který nám není příliš vzdálen, tedy léta 1948-1989, je navýsost atraktivní, ale i věcně aktuální, nepochybuji. Jisté nebezpečí spatřuji ovšem v tom, že zápal mladistvých nadšenců vede k objevování toho, co poněkud poučená starší generace zná jako trivium. Tak např́klad „mechanismy vládnutí“ nepokládám za téma, kde by bylo co objevovat. Za daleko cennější pokládám naopak některé práce literárních historiků, kteří s dostatečnou akribií popsali roli literatury a spisovatelů tohoto období - padni, komu padni. 
Je nanejvýš zajímavé, že i když jednou z hlavních inspirací pro novou historickou sociologii je marxismus, domněle marxistická sociologie $v$ Polsku a Česku nejevila žádný zájem o touto (pro marxismus koneckonců kanonickou!) problematiku a nevytvořila vlastní školu historické sociologie. České dějepisectví a jména jako třeba Otto Urban nebo Miroslav Hroch ale dokazují, že ani v našich zemích marxismus nebýval vždycky úplně sterilní a mohl se stát určitou inspiraci. Proč se jím nestal pro sociology?

Protože je nečetli. Urban sice byl marxista „ex offo“, ale v desítkách rozhovorů, které jsem s ním vedl v Univerzitní knihovně a v kavárně UMPRUM, jsem se mohl přesvědčit, že marxismus bral jako vážnou inspiraci - nic více a nic méně. Jeho malá knížka o vzniku kapitalismu v Čechách je i dnes nesmírně inspirativní. Ostatně ve své velké monografii o české společnosti 19. století po letech nařízeného mlčení se tam objevuje nezkreslená velká postava Masarykova. A profesor Hroch, který je asi ve světě nejznámějším českým historikem, vzal marxismus stejně vážně a dokázal, že není třeba bít se v prsa - jestliže nejsme upřímnými kajícníky. A on pro to nemá důvod. Máme dva velké historicky myslící a inspirující myslitele - především profesora Bedřicha Loewensteina (žije v Německu), jehož knihy o modernitě a zejména jeho poslední syntetická práce o pokroku by měly být povinným sociologickým čtivem (ale i drobná brožurka o revolucích). A samozřejmě profesora Jaroslava Krejčího, který žije v Británii, jehož syntetická práce o vývoji světových kultur a civilizací není sice „bezdiskusní“ - ale je mimořádně inspirativní. Ale kolik sociologů vůbec u nás tuší, že by Krejčího měli číst jako zdroj poučení a inspirace? Prostě si škodíme tím, že se nečteme. Navzájem. V záplavě informací a v době efemérních mód dokonce nepíšeme ani recenze na zásadní knihy české provenience, nejen sociologické, ale právě i historické, v nichž je sociologického poučení snad až nadbytek. Velmi bych si přál, aby časopis Historická sociologie obnovil „bláhovskou“ tradici pravidelného recenzování - i když za to nejsou ony „body“ pro jakési administrativní hodnocení (což znovu dokládá tupost jeho tvůrců), v Sociologické revui se přece hlavně hodně recenzovalo a svět měl tehdy čtyři světové strany. Inu - snad to bude tradice „bláhovská“ a nikoliv pouze „sen bláhový“. Obojí je možné, to druhé pravděpodobnější.

Když se dívám na českou a polskou sociologii, mám dojem, že Češi přikládají nesrovnatelně větši význam velké teorii - v Polsku se jí zabývá jen pár lidí, v Česku každý druhý vědec. Občas jde o až př́liš abstraktni a možná tedy i poněkud anachronickou grounded theory. Jak bys vysvětlil tento rozdíl, pokud se samozřejmě domníváš, že opravdu o nějaký rozdíl jde?

Myslím, že my dva jsme př́kladem toho, jak lze tentýž fenomén vidět různými optikami a s různými akcenty. Neskromně konstatuji, že právě v posledním čísle Sociologického časopisu vychází můj článek o „návratu sociologické teorie do Čech“, kde konstatuji jako premisu, že česká sociologie byla a je silně ateoretická a pokud teoretizovala, pak spíše spekulovala. Vím o dvou solidních pracích, které se o jakousi „grounded theory“ pokoušejí, o knihách Jana Balona a Marka Nohejla - ale to jsou naprosté výjimky. Jistě i Baršova kniha Imanence a sociální pouto do této kategorie patří, nicméně v podstatě jde o práci par excellence filosofickou, sociologický je vlastně jen závěr, kde se prolíná filosofie, sociologie a „politologický obrat“ reprezentovaný Habermasem. Na druhé straně zájem mladých o sociologickou (či sociální) teorii nepokládám vůbec za negativum, spíše se naopak obávám vlivu módních teorií, které zůstávají nestráveny - foucaultovská 
móda sice pominula (historický rozměr Foucaultova díla zůstal však jaksi pominut, jakkoliv je v mnoha ohledech pochybný, což ovšem žel zčásti platí i o Baumanově analýze holocaustu), ale tzv. kvalitativní sociologie bují v podobách nadměrných. Tam, kde by mohlo jít o př́spěvek k historické sociologii, třebas při aplikaci diskursivní analýzy, se zůstává na povrchních rozhovorech o ničem a zaštítí se to „grounded theory“, která se v práci samé nikdy nikde, kromě proklamativního úvodu, neobjeví. Naše „gender studies“ jsou bohatě rozvinuty, ale uzavřeny do sebe sama - téma „žena v dějinách“ dělají skvěle historičky a historici, nikoliv naše bojovnice za ženská práva. Ale ani tady bez historické komparace nelze ničemu kloudně porozumět.

Jsi jeden s mála sociologů, kteř́ nejen jeví pouze zájem o literaturu - v Tvém př́padě dokonce o umění vỉbec - ale jsou ho schopni propojit se svou badatelskou praxí. Samozrrejmě máš v tom velkého předchůdce v osobě T. G. Masaryka. Co Ti dává jakožto historickému sociologovi (pokud mi přece jen dovolíš použít tento pojem) literatura?

Dnes se již dozajista nestanu „historickým sociologem“, ačkoliv souvztažnost „dějin“ a „soudobé společnosti“ jsem vždycky chápal jako souvztažnost naprosto podstatnou. Ale přece jen - před lety jsem četl zajímavý nedokončený esej Liona Feuchtwangera Desdemonin di̊m, esej o historickém románu, inspirovaný mimo jiné Lukácsovým pojetím historického románu jako dvoulomého fenoménu: obvykle bud’ autor do nějaké historické epochy vkládá své ideje, názory, pocity a situace, které ho zajímají a „historická situace“ tvoří pouze kulisy ahistorického děje, nebo autor píše tak, že v postavách i ději vychází z dané epochy a pokud je to možné respektuje jejího „ducha“. Jistě, lze se obrátit ke croceovskému prezentismu a namítnout, že žádná přesvědčivá empatie, která by romanopisci umožňovala zachytit dobu a její specifika, prostě neexistuje, každý historický román je vždycky (také) „románem o nás“. To je námitka banální a ne zcela přesvědčivá. Feuchtwanger namítá - „vnitřní lidská podstata zůstává po staletí nezměněna a kdyby si historické dílo tuto skutečnost neuvědomovalo, chyběla by mu vnitřní pravdivost“. Takže onu prezentistickou tezi lze i obrátit - my se nacházíme v historických dějích právě proto, že jsme stejné podstaty jako naši dávní předchůdci. Tím se jaksi řeší i slavný „Marxův paradox“, jenž si kladl otázku, jak je možné, že nás antická tragédie, vzniklá v archaické epoše lidských dějin, stále ještě vzrušuje. Jednoduše řečeno - čím může být (a je) „aktuální“ Antigona? Čím je aktuální Romeo a Julie je nasnadě, ale čím je aktuální Král Lear? Krásná literatura nám umožňuje tedy pohled nejen do minulosti, ale i do našich vlastních, zejména existenciálních otázek. Ostatně Camus byl přesvědčen, že literatura, která na takové otázky neodpovídá, vlastně literaturou sensu stricto ani není. Není místo na rozvedení teze, že samozřejmě tatáž epocha má své romanopisce píšící z různých zorných úhlů, řečeno módním bourdieuovským - na základě odlišných „habitů“. Slavná věta Lévi-Strausse, že dějiny francouzské revoluce vyprávěné jakobínem jsou jiné než tytéž dějiny vyprávěné monarchistou, jistě platí i pro historickou beletrii. O to zajímavější je číst Balzacovy Jouany a Hugovo Devadesát tři nebo z jiného soudku Šolochovův Tichý Don a Pasternakova Doktora Živaga (ačkoliv, přísně vzato, on tam tak veliký rozdíl ve vidění občanské války není).

Dodám - moji studenti, jakkoliv pilně chodí na přednášky o „filosofii dějin pro sociology“, strašně neradi čtou historickou beletrii a já pro to nemám vysvětlení. Vždycky uhnou k Orwelovi nebo jiné dystopii nebo mě přesvědčují, že nějaká fantasy je vlastně 
historický př́iběh. A přece o nějaké přesycenosti „historismem“ nemůže být ani řeči. Máš na tuto otázku odpověd?

To srovnání s Masarykem je sice lichotivé, ale nebudu předstírat skromnost: Masaryk četl podobně, hledal tam stejně obraz minulosti (který pak vedl k jeho spekulativní konstrukci smyslu českých dějin) jako odpověd’ na základní otázky našeho lidství. Proto mu byl Dostojevskij klíčem nejen k Rusku, ale i k lidské duši celé.

$V$ posledni době pravidelně vydáváš menši a větši práce týkajicí se současnosti - naposledy sbírku esejů Společnost naší doby napsaných společně s Janem Balonem. A čím se zabýváš právě v této době? Dočkáme se i nějaké, snad rozsáhlejší publikace, v nichž by ses vyjádřil na téma dějin a literatury? By the way: nestálo by za to vydat znova, možná $v$ přepracované podobě, Tvou skvělou knižečku o sociologii a literatuře publikovanou pưvodně $v$ roce 1990 ?

Ted’ písuu hesla do slovníku českých sociologů, je to trochu únavné, ale co naplat. Mám nachystánu a zčásti napsánu knížku, která by měla být jakousi spojnicí mezi politickými dějinami, dějinami idejí, včetně literatury (a snad i výtvarného umění) a „čistou sociologií“.

Je to jakási „sociologie na útěku“, knížka vycházející z premisy, že 20. století bylo stoletím bezprecedentního vynuceného pohybu lidí a idejí, tedy paradoxně vynuceného vzájemného obohacování kultur a společností - frankfurtská škola, Schütz a Arendtová v Americe, Popper v Austrálii, Aron a potom Bauman v Anglii, Berdjajev ve Francii a k tomu přičtěme spisovatele, Canettiho, Miłosze, Kunderu, ale taky Kokoschku a jiné představitele „entartete Kunst“. Je to fascinující, jakkoliv mrazivý obraz doby. A to pomíjím ty, kteři zůstali - Heideggera, Jüngera, Schmitta, Eliada a spoustu jiných. Kdyby se to podařilo... snad bych konečně měl něco solidního za sebou.

Ten nápad reeditovat starou knížečku je sice lichotivý, ale představa, že obraz sociologie literatury se změnil natolik podstatně, že většina z toho, co tam je, jsou vlastně archaismy, je natolik úděsná, že vede k rezignaci. Napsal bych další knihu, přičemž některé texty lze překonat - jakékoliv výhrady k nim mohu mít - jen opravdu stěží. Třebas ten konvolut Pierra Bourdieua...

Děkuji za rozhovor, srdečně blahopřeji k významnému jubileu a doufám, že budu - společně se čtenáři „Historické sociologie“ - ještě dlouho čerpat poučeni a potěšení z výsledků Tvé vědecké a spisovatelské práce.

Miloslav Petrusek (1936), přední český sociolog, vyučujicí na Fakultě sociálních věd Univerzity Karlovy v Praze, v letech 1991-1997 byl také jejím děkanem. V obdobi 1997-2000 zastával funkci prorektora Univerzity Karlovy. Pracuje mimo jiné v oblasti teoretické sociologie a sociologie soudobých společností. Byl kupř́kladu redaktorem Velkého sociologického slovníku (1996). Mezi jeho práce posledni doby patři tituly Společnosti pozdní doby (2006), Dějiny sociologie (2011, vedoucí autorského kolektivu) a Společnost naší doby (2011, společně s Janem Balonem). 